\title{
Distribution of Dystrophin and Dystrophin-Associated Protein 43DAG ( $\beta$-dystroglycan) in the Central Nervous System of Normal Controls and Patients with Duchenne Muscular Dystrophy
}

\author{
Makoto Uchino, Akio Hara, Yuji Mizuno*, Michihiro Fujiki, Tetsuji NaKamura**, Makoto Tokunaga, \\ Teruyuki Hirano, Taro Yamashita**, Ei-ichiro Uyama, Yukio Ando**, Shuji Mita and Masayuki Ando**
}

In skeletal muscles of patients with Duchenne muscular dystrophy (DMD), the absence of dystrophin was thought to lead to the large reduction in all of the dystrophin-associated proteins (DAPs). Of the seven types of DAPs identified in skeletal muscle, only the 43-kDa glycoprotein ( $\beta$ dystroglycan) has recently been found in the monkey brain. To clarify the distribution and characterization of dystrophin and $\beta$-dystroglycan in the brain of humans, we carried out immunostaining and immunoblotting studies on tissues from three DMD patients with intellectual disturbances (ages 17, 22, and 26 year) and in five controls (age range, 42-74 year). An antidystrophin antibody revealed dystrophin to be localized in neuronal cells and in the vascular wall in control brains, but it was absent from these tissues in DMD patients. In contrast, $\beta$-dystroglycan was distributed throughout neuronal cells and in the vascular wall of control brains, and was well preserved in the brain of patients with DMD.

(Internal Medicine 35: 189-194, 1996)

Key words: brain type dystrophin, immunostaining, immunoblotting, neuronal cells, dystrophinassociated protein

\section{Introduction}

The gene for Duchenne muscular dystrophy (DMD) encodes dystrophin, a large membrane cytoskeletal protein found in skeletal muscle (1-4). This protein is localized on the inner surface of the sarcolemma in normal skeletal muscle, but is absent from the skeletal muscle of patients with DMD (5-9). Since the discovery of dystrophin, dystrophin-associated proteins (DAPs) (10-15), utrophin $(16,17)$, and several dystrophin isoforms such as Dp71 $(18,19), 75-\mathrm{kDa}$ protein $(20)$, apodystrophin-1 and $-3(21,22)$, and Dp116 (23) have been described. Campbell and Kahl (10) demonstrated that dystrophin is tightly linked to a large oligomeric complex of sarcolemma glycoproteins. Ervasti et al (11) and Yoshida and Ozawa (15) showed that the glycoproteins are comprised of a $156-\mathrm{kDa}$ glycoprotein ( $\alpha$-dystroglycan), a $94-k D a$ protein $(\mathrm{A} 0)$, three kinds of 59-kDa protein ( $\alpha-, \beta_{1^{-}}, \beta_{2}$-syntrophins), a $50-\mathrm{kDa}$ glycoprotein ( $\alpha$-sarcoglycan), two 43-kDa glycoproteins ( $\beta$ - dystro-glycan and $\beta$-sarcoglycan), a 35-kDa glycoprotein ( $\gamma$ sarcoglycan), and a 25-kDa protein (25DAP). Yoshida et al (24) showed that there is an additional $43 \mathrm{kDa}$ glycoprotein $\beta$ sarcoglycan which is differentiated from $\beta$-dystroglycan, on the basis of several criteria. It has been proposed that $\alpha$ dystroglycan and $\beta$-dystroglycan span the sarcolemma to provide a link between the subsarcolemmal cytoskeleton and the extracellular matrix component, laminin $(12,25,26)$.

Campbell's group reported that, in the skeletal muscle of patients with DMD, the absence of dystrophin led to a large reduction in all DAPs $(11,25,27)$. Conversely, Yoshida et al (28) and Mizuno et al (29) demonstrated that $\beta$-dystroglycan is rather well retained in DMD muscle, as compared with adhalin. $\beta$-dystroglycan and adhalin each belong to different groups of DAP (24). We reported earlier on the localization of dystrophin and utrophin in humans (30) and in murine brains (31). We describe here the localization and characterization of dystrophin and $\beta$-dystroglycan in the human brain.

From the Department of Neurology, **the First Department of Internal Medicine, Kumamoto University School of Medicine, Kumamoto and *National Institute of Neuroscience, NCNP, Kodaira

Received for publication July 17, 1995; Accepted for publication November 22, 1995

Reprint requests should be addressed to Dr. Makoto Uchino, the Department of Neurology, Kumamoto University School of Medicine, 1-1-1 Honjo, Kumamoto 860 


\section{Subjects and Methods}

The brains and skeletal muscles were obtained at autopsy from three male patients (ages 17,22, and 26 year) with DMD and from five controls (four men and one woman aged 42-74 year) who died from causes other than neurological or psychiatric disease. Autopsy was done within 4 hours of death. All of the subjects were Japanese. The recorded IQ scores of the three DMD patients were 61,68 , and below 50 , respectively (tested with the Wechsler Intelligence Scale for Children-Revised or the Wechsler Adult Intelligence Scale). Tissues were divided into frontal, parietal, and occipital lobes, cerebellum, and skeletal muscle and were immediately frozen in liquid nitrogen- cooled isopentane and stored in a deep freezer $\left(-85^{\circ} \mathrm{C}\right)$ until the start of the experiments.

For immunostaining, frozen sections were cut into $10 \mu \mathrm{m}$ sections and stained by the avidin-biotinylated horseradish peroxidase method, as described previously $(30,31)$. For primary incubation, two types of region-specific antidystrophin antibodies were used: rabbit antidystrophin antibody (antibody 6-10) and mouse antidystrophin antibody (Dys-2; Novocastra Laboratories, Newcastle upon Tyne, UK). Antibody 6-10 is a polyclonal antibody that is produced in a rabbit immunized with a dystrophin polypeptide expressed in $E$. coli from dystrophin cDNA residues 6,181-9,544; it is excellent for the detection of brain-type dystrophin. Dys-2 is a monoclonal antibody raised
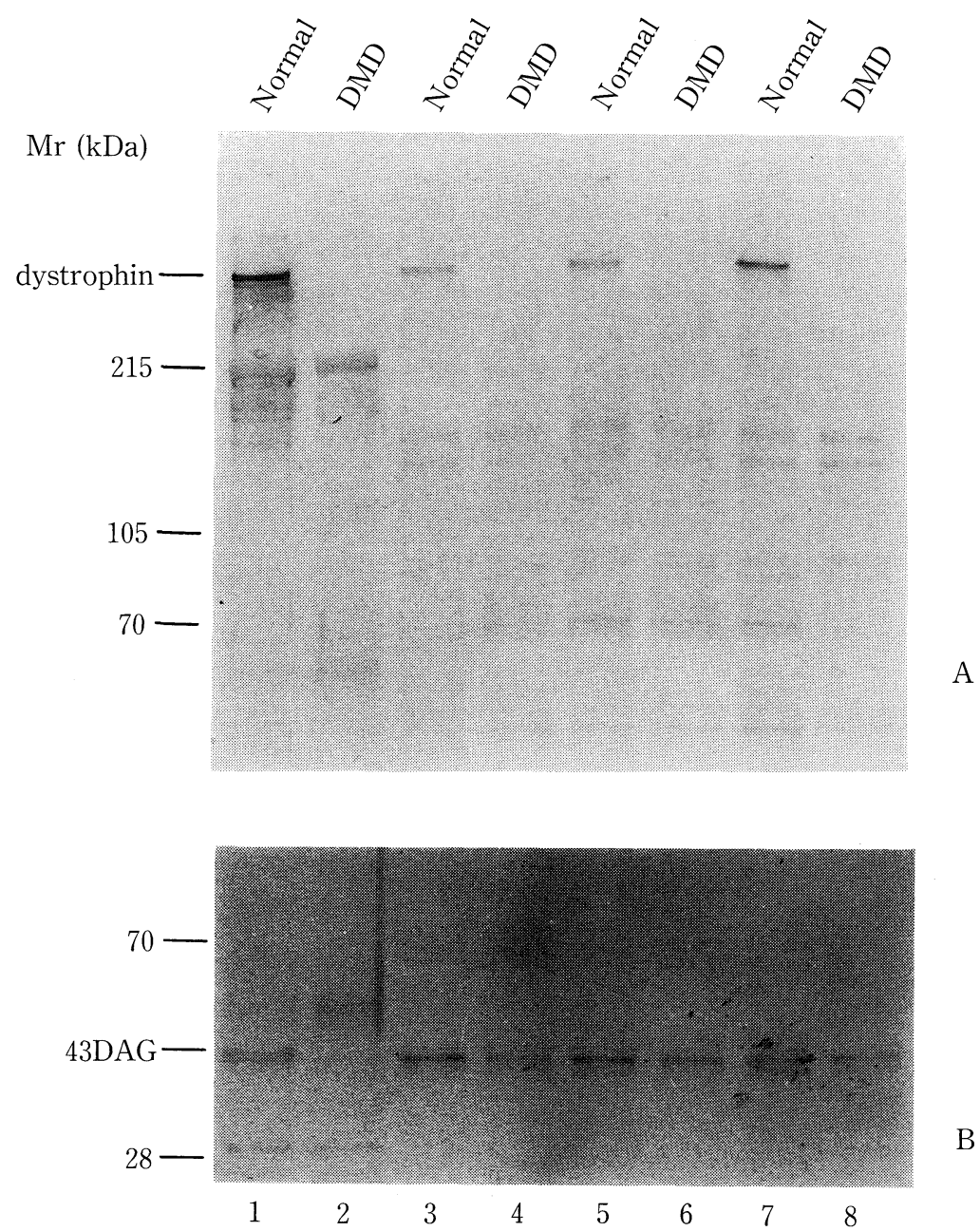

Figure 1. Immunoblot of the brain and skeletal muscle from a normal control and a patient with DMD. Normal control, lanes 1,3,5,7; DMD, lanes 2, 4, 6, 8. Lanes 1 and 2, skeletal muscle; lanes 3 and 4, frontal lobe; lanes 5 and 6, parietal lobe; lanes 7 and 8, cerebellum. Blots were stained with antibody 6-10 (Panel A) and antibody PA3a (Panel B). The dystrophin band is clear in the normal control brain (lanes 1, $3,5,7$ ), but it is not evident in the DMD brain (lanes $2,4,6,8$ ). With antibody PA3a, the $43 \mathrm{kDa}$ band ( $\beta$-dystroglycan) was clearly evident in control skeletal muscle and brain. In DMD, the $43 \mathrm{kDa}$ band was very faint in skeletal muscle, but was clearly noted in brain tissue. 
against the 3,669-3,685 (C terminus). For the detection of 43DAG, we used antibody PA3a, a polyclonal anti-43DAG antibody raised in a rabbit against synthetic polypeptide, that corresponds to the internal amino acid sequence determined by microsequence analysis (28). For immunoblot studies, tissues were homogenized in a buffer containing $2 \%$ SDS, $5 \% \beta$ mercaptoethanol, 4 mM EDTA, 1 mM PMSF, $40 \mathrm{mM}$ Tris, 0.24 $\mathrm{M}$ glycine, $40 \%$ glycerine, and $0.001 \%$ bromphenol blue $(\mathrm{pH}$

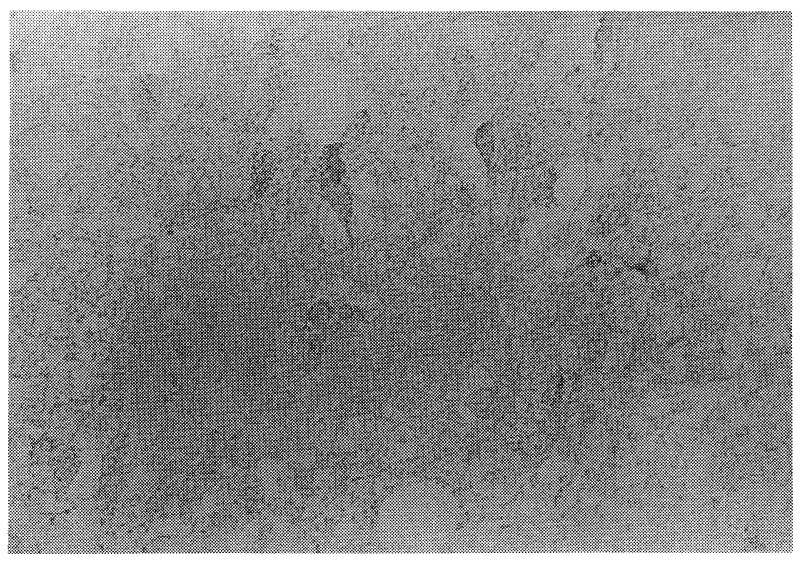

A

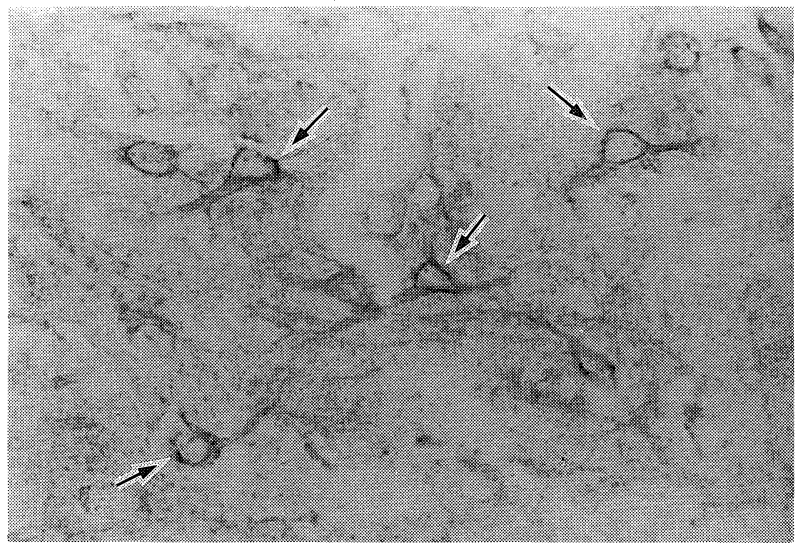

C

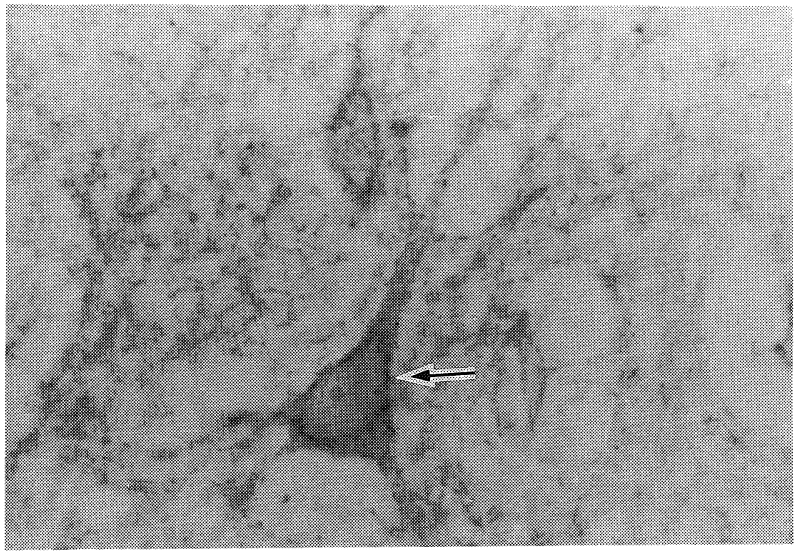

E

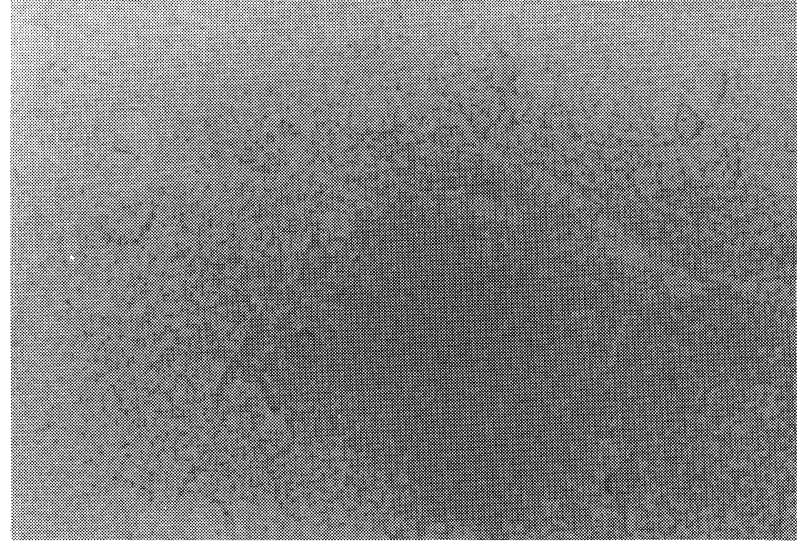

B

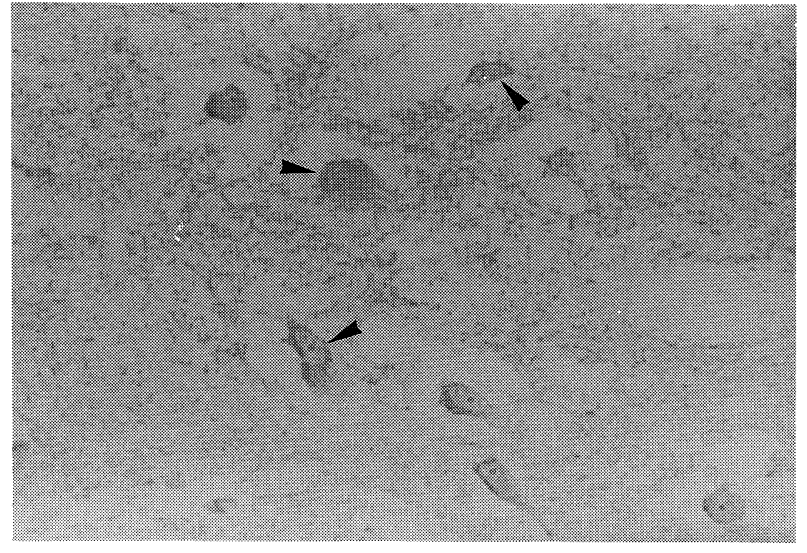

D

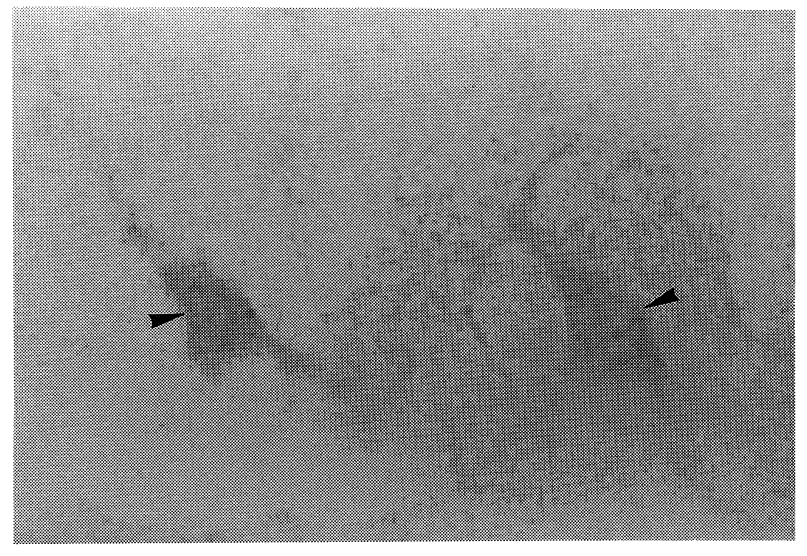

$\mathrm{F}$

Figure 2. Immunohistochemical localization of dystrophin in the cerebral cortex of a normal control (A, C, E) and a DMD patient $(\mathrm{B}, \mathrm{D}, \mathrm{F})$, labeled with preimmune serum $(\mathrm{A}, \mathrm{B})$ and antidystrophin antibody (antibody 6-10) (C-F). Punctate immunoreactivity was evident along the surface membranes of cell bodies and dendrites of the control cerebral cortical neurons (arrows), but immunoreactivity was absent in DMD (arrowheads) (A-D, $\times 330 ; \mathrm{E}, \mathrm{F}, \times 825)$. 


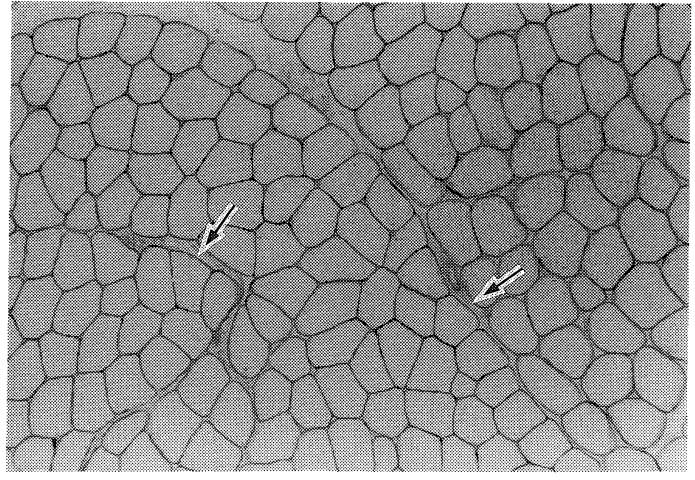

A

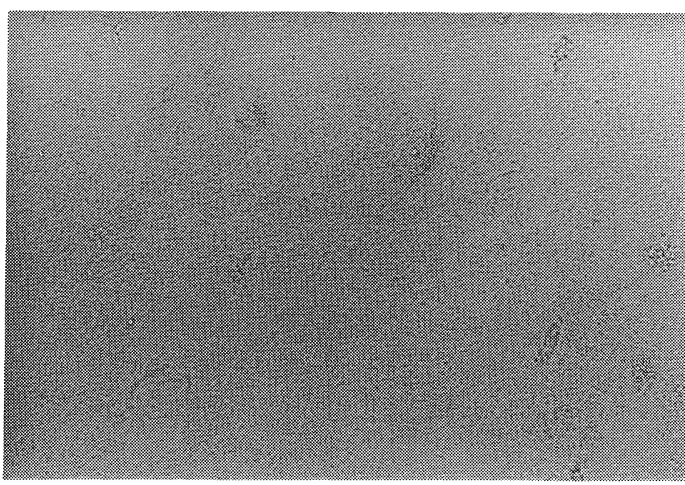

C

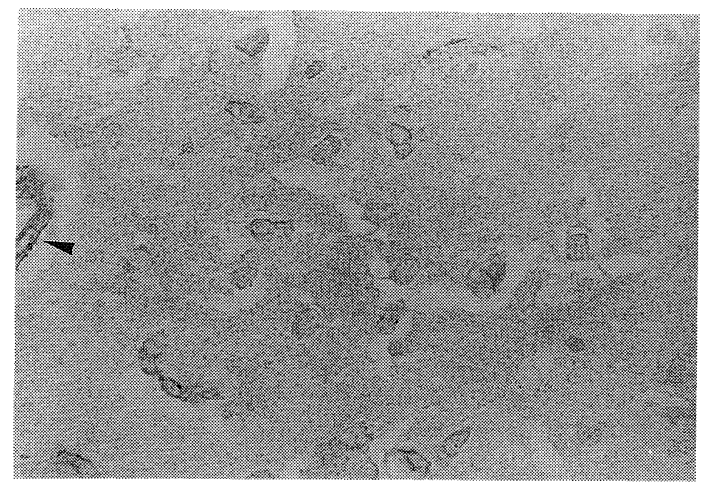

E

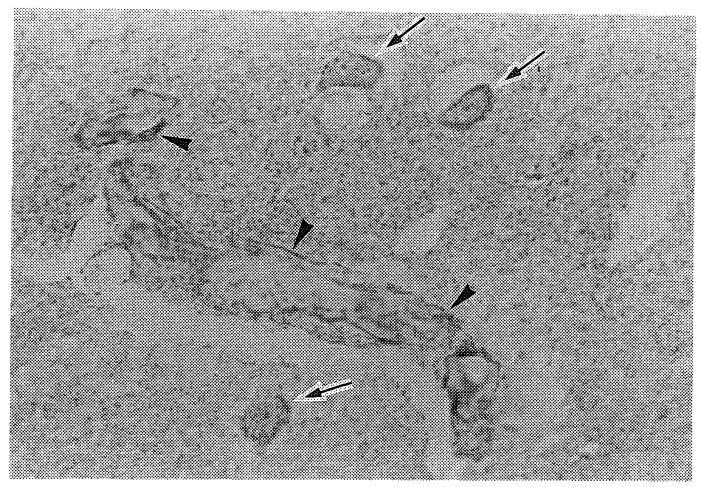

G

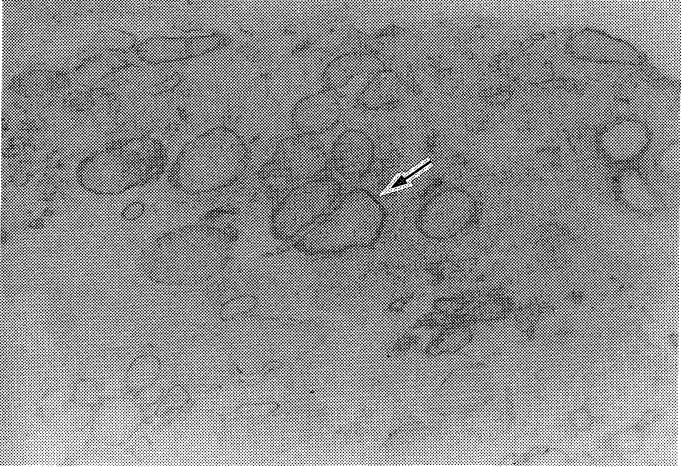

B

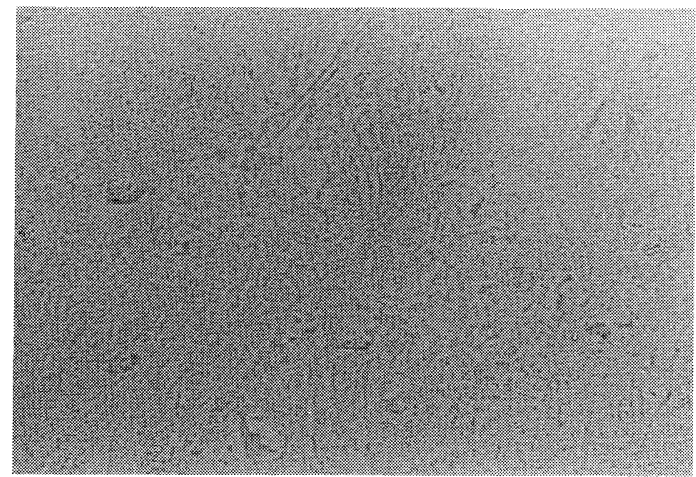

D

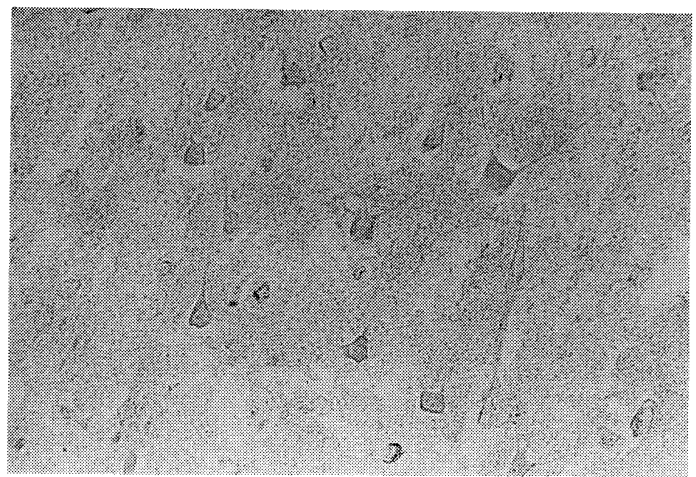

F

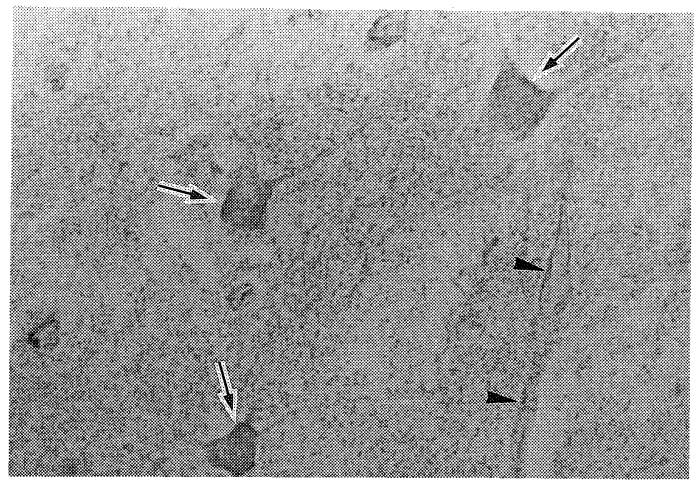

$\mathrm{H}$

Figure 3. Immunohistochemical localization of $\beta$-dystroglycan in skeletal muscle (control, A; DMD, B), cerebral cortex (control, C, E, and G; DMD, D, F, and H), labeled with preimmune serum $(C, D)$ and antibody PA3a (E-H). Positive labeling was evident along the sarcolemma (A, B; arrows), the surface membrane of neurons (E-H; arrows) and the vascular wall (E-H; arrowheads) (A, B, $\times 83 ; \mathrm{C}, \mathrm{D}, \times 330 ; \mathrm{E}, \mathrm{F}, \times 250 ; \mathrm{G}, \mathrm{H}, \times 550)$. 


\section{Dystrophin and $\beta$-Dystroglycan in DMD Brain}

8.5). Ten micrograms of protein were electrophoresed through 3.5 to $12 \%$ SDS polyacrylamide gradient gels $(1 \mathrm{~mm} \times 10 \mathrm{~cm}$ $\times 9 \mathrm{~cm})$ at $15 \mathrm{~mA}$ for 2.5 hour. After transfer onto a membrane (Immobilon-P, Millipore Corporation, Bedford, MA, USA), the specimen was blocked with $0.1 \%$ casein- $0.1 \%$ gelatin in PBS overnight at $4^{\circ} \mathrm{C}$; blots were stained with antidystrophin and anti- $\beta$-dystroglycan antibodies at room temperature for 2 hour. Dystrophin-antidystrophin and $\beta$-dystroglycan-anti- $\beta$ dystroglycan immune complexes were detected with affinitypurified secondary antibodies conjugated to avidin-biotinylated horseradish peroxidase (Vecstain ABC kit and Elite ABC kit, Vector Laboratories, Burlingame, CA, USA). For statistical analysis, the $\beta$-dystroglycan band was measured using a densitometer (Cosmo F808, Cosmo Co. Tokyo, Japan).

\section{Results}

\section{Immunoblots}

Following immunoblots of the control cerebrum (frontal, parietal, and occipital lobes), cerebellum, and skeletal muscle, antibody 6-10 revealed a clear dystrophin band at $427 \mathrm{kDa}$ and this band was absent in brain and skeletal muscles from DMD patients (Fig. 1A). With Dys-2, no dystrophin band was noted in either control or DMD brains (data not shown). With antibody PA3a, the $\beta$-dystroglycan band was clearly noted at 43 $\mathrm{kDa}$ in all brains examined and there was no significant difference in the density of the 43DAG band between DMD and control brains (Fig. 1B). The $\beta$-dystroglycan band of skeletal muscle was clear in controls, but very faint in advanced DMD.

\section{Immunostain}

With immunostaining, antibody 6-10 was localized in a punctate manner along the cell bodies and dendrites of cerebral cortical neurons and Purkinje cells of control brains, but was absent in the brains of DMD (Fig. 2). With Dys-2, the vascular wall was positively labeled in control brains, but cerebral cortical neurons and Purkinje cells did not stain positively in either control or DMD brains. With antibody PA3a, the surface membranes of cerebral cortical neurons, Purkinje cells, pia mater, and the vascular wall were positively stained in all of the brains examined (Fig. 3).

\section{Discussion}

The absence of dystrophin dramatically reduced all the DAPs in the sarcolemma of patients with DMD and of $\mathrm{mdx}$ mice $(11,25,27)$. Yoshida et al (28) and Mizuno et al (32) demonstrated that $\beta$-dystroglycan is retained in DMD muscles, as determined using anti- $\beta$-dystroglycan antibody (PA3a). In the present study, sarcolemma of the DMD muscle was fairly well stained with PA3a but the amount of $\beta$-dystroglycan was reduced on immunoblots, probably due to the severe decrease in the total number of muscle fibers. In the DAPs, $\beta$-dystroglycan was present in monkey brain (32). We investigated the distribution and characterization of dystrophin and $\beta$-dystroglycan in the human brain. Although the localization of dystrophin in the
CNS has been clarified in an animal model and in humans (3335 ), its role in the CNS is not clear. Mental retardation and decreased intellectual function are frequently noted in DMD patients (36-42). However, intellectual disturbance in DMD is not progressive, and there is no necrosis and/or degeneration of cortical neurons in the brain of such patients which is in contrast to findings in their muscles. Using antibody 6-10, we found that dystrophin was localized in neuronal cells of the control brains but was absent from neuronal cells in the brains of DMD patients with intellectual disturbances. In contrast, $\beta$ dystroglycan was well distributed in the control brains and was well preserved in DMD brains. Obviously, a deficiency of dystrophin does not always lead to a marked reduction of DAP in the DMD brain. Retention of DAP 43DAG may possibly be related to the preservation of neurons in the DMD brain.

In DMD patients, we confirmed that there is a lowering of the IQ and also an abnormality of event-related brain potentials (P300) (unpublished data). Pillers et al (43) reported evidence of dystrophin in the outer plexiform layer of the human retina, and found that five patients with Becker's dystrophy and six with Duchenne dystrophy had abnormal electroretinograms. These data suggest that dystrophin is related to the diversified physiological functions in tissues.

Acknowledgements: We thank Drs. E. Ozawa (The National Institute of Neuroscience, Japan), L.M. Kunkel, and H.G.W. Lidov (Department of Pediatrics, Harvard Medical School and The Howard Hughes Medical Institute, Division of Genetics, Children's Hospital, Boston, MA, USA) for the generous donation of rabbit anti- $\beta$-dystroglycan antibody (PA3a) and antibody 6-10. This work was supported by a grant (2-A) from the National Center of Neurology and Psychiatry (NCNP) of the Ministry of Health and Welfare, Japan.

\section{References}

1) Hoffman EP, Knudson CM, Campbell KP, Kunkel LM. Subcellular fractionation of dystrophin to the triads of skeletal muscle. Nature 330: $754,1987$.

2) Hoffman EP, Brown RH, Kunkel LM. Dystrophin: the protein product of the Duchenne muscular dystrophy locus. Cell 51: 919, 1987.

3) Koenig M, Monaco AP, Kunkel LM. The complete sequence of dystrophin predicts a rod-shaped cytoskeletal protein. Cell 53: 219, 1988.

4) Koenig M, Kunkel LM. Detailed analysis of the repeat domain of dystrophin reveals four potential hinge segments that may confer flexibility. J Biol Chem 265: 4560, 1990.

5) Arahata $\mathrm{K}$, Ishiura $\mathrm{S}$, Ishiguro $\mathrm{T}$, et al. Immunostaining of skeletal and cardiac muscle surface membrane with antibody against Duchenne muscular dystrophy peptide. Nature 333: 861, 1988.

6) Hoffman EP, Fischbeck KH, Brown RH, et al. Characterization of dystrophin in muscle-biopsy specimens from patients with Duchenne's or Becker's muscular dystrophy. N Engl J Med 318: 1363, 1988.

7) Sugita $H$, Arahata $K$, Ishiguro $T$, et al. Negative immunostaining of Duchenne muscular dystrophy (DMD) and mdx muscle surface membrane with antibody against synthetic peptide fragment predicted from DMD cDNA. Proc Jpn Acad 64: 37, 1988.

8) Watkins SC, Hoffman EP, Slayter HS, Kunkel LM. Immunoelectron microscopic localization of dystrophin in myofibres. Nature 333: 863, 1988.

9) Zubrzycka-Gaarn EE, Bulman DE, Karpati G, et al. The Duchenne muscular dystrophy gene product is localized in sarcolemma of human skeletal muscle. Nature 333: 466, 1988.

10) Campbell KP, Kahl SD. Association of dystrophin and an integral 


\section{UCHINO et al}

membrane glycoprotein. Nature 338: 259, 1989.

11) Ervasti JM, Ohlendieck K, Kahl SD, Gaver MG, Campbell KP. Deficiency of a glycoprotein component of the dystrophin complex in dystrophic muscle. Nature 345: 315, 1990.

12) Ervasti JM, Kahl SD, Campbell KP. Purification of dystrophin from skeletal muscle. J Biol Chem 266: 9161, 1991.

13) Ervasti JM, Campbell KP. Membrane organization of the dystrophinglycoprotein complex. Cell 66: 1121, 1991.

14) Yamamoto H, Hagiwara Y, Mizuno Y, Yoshida M, Ozawa E. Heterogeneity of dystrophin-associated proteins. J Biochem 114: 132, 1993.

15) Yoshida M, Ozawa E. Glycoprotein complex anchoring dystrophin to sarcolemma. J Biochem 108: 748, 1990.

16) Love DR, Hill DF, Dickson G, et al. An autosomal transcript in skeletal muscle with homology to dystrophin. Nature 339: 55, 1989.

17) Love DR, Byth BC, Tinsley JM. Dystrophin and dystrophin-related proteins: a review of protein and RNA studies. Neuromusc Disord 3: 5, 1993.

18) Bar S, Barnea E, Levy Z, Neuman S, Yaffe D, Nudel U. A novel product of the Duchenne muscular dystrophy gene which greatly differs from the known isoforms in its structure and tissue distribution. Biochem J 272: $557,1988$.

19) Lederfein D, Levy Z, Augier N, et al. A 71-kilodalton protein is a major product of the Duchenne muscular dystrophy gene in brain and other nonmuscle tissues. Proc Natl Acad Sci USA 89: 5346, 1992.

20) Hugnot JP, Gilgenkrantz H, Vincent N, et al. Distal transcript of the dystrophin gene initiated from an alternative first exon and encoding a 75$\mathrm{kDa}$ protein widely distributed in nonmuscle tissues. Proc Natl Acad Sci USA 89: 7506, 1992.

21) Blake DJ, Love DR, Tinsley JM, et al. Characterization of a $4.8 \mathrm{~kb}$ transcript from the Duchenne muscular dystrophy locus expressed in Schwannoma cells. Hum Mol Genet 1: 103, 1992.

22) Tinsley JM, Blake DJ, Davies KE. Apo-dystrophin-3: a 2.2kb transcript from the DMD locus encoding the dystrophin glycoprotein binding site. Hum Mol Genet 2: 521, 1993.

23) Byers TJ, Lidov HGW, Kunkel LM. An alternative dystrophin transcript specific to peripheral nerve. Nature Genet 4: 77, 1993.

24) Yoshida M, Suzuki A, Yamamoto H, Noguchi S, Mizuno Y, Ozawa E. Dissociation of the complex of dystrophin and its associated proteins into several unique groups by n-octyl- $\beta$-D-glucoside. Eur J Biochem 222: 1055, 1994.

25) Ibraghimov-Beskrovnaya O, Ervasti JM, Leveille CJ, Slaughter CA, Sernett SW, Campbell KP. Primary structure of dystrophin-associated glycoproteins linking dystrophin to the extracellular matrix. Nature 355: 696, 1992.

26) Suzuki A, Yoshida M, Hayashi K, Mizuno Y, Hagiwara Y, Ozawa E. Molecular organization at the glycoprotein-complex-binding site of dystrophin. Eur J Biochem 220: 283, 1994.
27) Ohlendieck K, Matsumura K, Ionasescu VV, et al. Duchenne muscular dystrophy: deficiency of dystrophin-associated proteins in the sarcolemma. Neurology 43: 795, 1993.

28) Yoshida M, Mizuno Y, Nonaka I, Ozawa E. A dystrophin-associated glycoprotein, A3a (one of 43DAG doublets), is retained in Duchenne muscular dystrophy muscle. J Biochem 114: 634, 1993.

29) Mizuno Y, Yoshida M, Nonaka I, Hirai S, Ozawa E. Expression of utrophin (dystrophin-related protein) and dystrophin-associated glycoproteins in muscles from patients with Duchenne muscular dystrophy. Muscle Nerve 17: 206, 1994.

30) Uchino M, Teramoto H, Naoe H, Miike T, Yoshioka K, Ando M. Dystrophin and dystrophin-related protein in the central nervous system of normal controls and Duchenne muscular dystrophy. Acta Neuropathol 87: 129, 1994.

31) Uchino M, Yoshioka K, Miike T, et al. Dystrophin and dystrophin-related protein in the brains of normal and mdx mice. Muscle Nerve 17: 533, 1994.

32) Mizuno Y, Yoshida M, Yamamoto H, Hirai S, Ozawa E. Distribution of dystrophin isoforms and dystrophin-associated proteins 43DAG (A3a) and 50DAG (A2) in various monkey tissues. J Biochem 114: 936, 1993.

33) Jung D, Pons F, Leger JJ, Aunis D, Rendon A. Dystrophin in central nervous system: a developmental, regional distribution and subcellular localization study. Neurosci Lett 124: 87, 1991.

34) Lidov HGW, Byers TJ, Watkins SC, Kunkel LM. Localization of dystrophin to postsynaptic regions of central nervous system cortical neurons. Nature 348: 725, 1990.

35) Uchino $M$, Teramoto $H$, Naoe $H$, Yoshioka $K$, Miike $T$, Ando $M$. Localization and characterization of dystrophin in the central nervous system of normal controls and Duchenne muscular dystrophy. J Neurol Neurosurg Psychiatry 57: 426, 1994.

36) Allen JE, Rodgin DW. Mental retardation in association with progressive muscular dystrophy. Am J Dis Child 100: 208, 1960.

37) Dubowitz V. Intellectual impairment in muscular dystrophy. Arch Dis Child 40: 296, 1965.

38) Marsh GG, Munsat TL. Evidence for early impairment of verbal intelligence in Duchenne muscular dystrophy. Arch Dis Child 49: 118, 1974.

39) Prosser EJ, Murphy EJ, Thompson MW. Intelligence and the gene for Duchenne muscular dystrophy. Arch Dis Child 44: 221, 1969.

40) Worden DK, Vignos PJ. Intellectual function in childhood progressive muscular dystrophy. Pediatrics 29: 968, 1962.

41) Zellweger H, Hanson JW. Psychometric studies in muscular dystrophy type IIIa (Duchenne). Dev Med Child Neurol 9: 576, 1968.

42) Zellweger $\mathrm{H}$, Niedermeyer $\mathrm{E}$. Central nervous system manifestation in childhood muscular dystrophy. Ann Paediatr 205: 25, 1965.

43) Pillers DM, Bulman DE, Weleber RG, et al. Dystrophin expression in the human retina is required for normal function as defined by electroretinography. Nature Genet 4: 82, 1993. 